DOI: 10.46340/eujem.2021.7.1.3

Inna Akhnovska, PhD in Economics

ORCID ID: https://orcid.org/0000-0001-9731-3801

Vasyl' Stus Donetsk National University, Ukraine

Olena Bratslavets

ORCID ID: https://orcid.org/0000-0002-6500-6054

Vasyl' Stus Donetsk National University, Ukraine

\title{
MARKET CATEGORY: ANALYTICAL REVIEW OF SCIENTIFIC THOUGHT DEVELOPMENT
}

\author{
Інна Ахновська, к. е. н. \\ Олена Брацлавець \\ Донецький національний університет імені Василя Стуса, Україна
}

\section{КАТЕГОРІЯ «РИНОК»: АНАЛІТИЧНИЙ ОГЛЯД РОЗВИТКУ НАУКОВОЇ ДУМКИ}

\begin{abstract}
One of the most important achievements of mankind is the market. In the conditions of technoglobalism the market is of great importance as a connecting link between commodity producers and consumers. Since there is no single point of view in the scientific literature on the essence of the market category, the aim of the article is to study the theoretical and methodological essence of the market and the evolutionary changes of this economic category. The article examines the evolutionary transformations of the market category over the last millennium. The interpretation of the market category in the works of domestic and foreign scholars and the approaches of researchers are considered. The author's definition of the market is given - it is an organized and balanced system, its elements are "demand", "supply", "competition" and "price", and they are in constant interaction; socio-economic relationships that take place in the exchange of goods, works, services and information between economic entities. Existing types and kinds of markets are revealed. The existing market functions, which are reflected in the scientific works of Ukrainian scholars, are analysed. The comparative characteristics of key market structures and their general differences are carried out. The tendencies of market development in the conditions of technoglobalism are identified. Consideration of the market as a system allowed to offer a spiral structure of the market life cycle in the main phases: pre-system state - slow growth - accelerated growth - increasing stabilization - reduced stabilization - slow reduction - rapid reduction - post-system state. The prospects for further research is the accumulation of scientific and methodological background for the development of the concept of market life cycle and the concept of market development in terms of technoglobalism.
\end{abstract}

Key words: market, technoglobalism, life cycle, market functions, types of markets, category, market evolution

Постановка проблеми. Ефективне функціонування будь-якої економічної системи, будь то окремий суб'єкт господарювання, економіка певного регіону, держави чи світової економіки загалом у довготривалому періоді із забезпеченням відповідного рівня розвитку і конкурентоспроможності можливе лише за умов якісного розвитку ринку, який є одним із найважливіших досягнень людства. В умовах техноглобалізму та відкритої економіки саме ринок, як сполучна ланка між товаровиробниками і споживачами, має велике значення.

Проблеми розвитку ринку розглядали багато зарубіжних і вітчизняних науковців, зокрема А. Сміт, Д. Рікардо, А. Курно, Ф. Котлер, А. Маршал, Д. Ліндсей, В. Андрійчук, В. Бойко, П. Гайдунський, О. Загороднюк, М. Коденська, В. Майн, С. Мочерний, О. Шпичак, В. Юрчишин та інші. Слід зазначити, що на сьогодні у науковій літературі не існує єдиної точки зору щодо сутності 
категорії «ринок», хоча вона є однією 3 найбільш розповсюджених в економічній теорії і широко вживаних у нашому суспільстві. Отже, це питання потребує подальшого грунтовного дослідження.

Формулювання цілей статті. Метою статті є дослідження теоретико-методологічної сутності функціонування ринку, еволюційних змін цієї економічної категорії, тенденцій розвитку ринку в умовах техноглобалізму та структури життєвого циклу ринку.

Опис основного матеріалу дослідження. Завдяки ринку суспільство вирішує три взаємопов'язані економічні проблеми: що має вироблятися і в якій кількості; як мають вироблятися ці товари (роботи, послуги); для кого призначені ці товари та як має розподілятися національний продукт між різними суб'єктами. Переважна більшість науковців відмічає необхідність розвитку вітчизняного ринку у відповідності із темпами розвитку світового ринку задля забезпечення відповідного рівня конкурентоспроможності вітчизняної економіки ${ }^{1}$. У той самий час, деякі вчені наголошують на значних проблемах у ринковій економіці України, які, незважаючи на істотний економіко-інфраструктурний потенціал, не дозволяють країні досягти рівня країн із розвиненою економікою. У значній мірі це відбувається через недосконалий механізм лібералізації ринку та часткову монополію в окремих нішах ${ }^{2}$. У контексті предметного розкриття проблематики даного наукового дослідження здійснимо аналіз трактування економічної категорії «ринок». Першу спробу надати наукове визначення ринку зробив французький економіст А. Курно, який наголошував на територіальних ознаках ринку ${ }^{3}$, хоча перші спроби визначити поняття були здійснені ще у Давньому Єгипті та Ассирії. Оксфордський словник зазначає, що вперше термін «ринок» був застосований у 1066 році ${ }^{4}$. Заслуговує на увагу дослідження Макаренко П.М. і Сень О.В., які розглядають ринок в організаційному та історичному плані - як публічне місце, простір (зону, територію); з позицій суспільного виробництва - як сферу обігу в загальній структурі виробництва; 3 точки зору суб'єктів і об’єктів - як сукупність економічних відносин різних суб'єктів 3 приводу обміну продуктами праці або діяльності. основ сутності ринку В. Майна ${ }^{6}$, який зазначає, що на теренах колишнього Радянського Союзу вперше поняття ринок було подано у Малій Радянській енциклопедії 1927 року. У дослідженні О. Афанасьєвої ${ }^{-7}$ виокремлюються 3 підходи до визначення ринку: $з$ точки зору економічної теоріїсукупність економічних відносин, що виникають між виробниками і споживачами у процесі вільного еквівалентного обміну виробленими благами; з точки зору маркетингу - як сукупність існуючих i потенційних покупців товару; з точки зору управління - як сукупність окремих видів ринку у межах національної економіки, які визначають структуру його системи. Грунтовно підійшов до дослідження гносеології поняття «ринок», як основної економічної категорії в контексті множини супутніх економічних категорій, Р. Логоша ${ }^{8}$, який виділяє 5 видів економік та - відповідно -5 видів ринків та етапів їх послідовних змін: I - первинна економіка - проторинок або економіка самозабезпечення (до XI століття); II - ринкова економіка; III - ринкова економіка з високим рівнем економічного лібералізму; IV - ринкова економіка тоталітарних суспільств; V - капіталізм як нова суспільноекономічна формація: ринкова економіка капіталістичного типу (з XVII ст.); індустріальне

\footnotetext{
${ }^{1}$ Олексенко, Р. І. (2018). Філософія ринкових відносин у історико-економічному дискурсі сучасних українських вчених. Гілея, 137, 79-90.

${ }^{2}$ Сімків, Л. С. (2020). Ринкова інфраструктура: елементи та значення в ринковій економіці. Socio-еconomic problems of the modern period of Ukraine, 4, 3-7.

3 Загороднюк, О. В. (2009). Теоретична сутність ринку, його функції та структурні складові. Формування ринкової економіки: збірник наукових працьь. Київ: ДВНЗ «Київський національний економічний університет ім. Вадима Гетьмана», 279-288.

${ }^{4}$ Oxford dictionary (1970). Market. Oxford: Clarendon Press, V-VI, 172-173.

${ }^{5}$ Макаренко, П. М., Сень, О. В. (2012). Теоретичні аспекти сутності ринку та його видів. Наукові праці Полтавської державної аграрної академії (ПДАА), 1 (4),2, 3-21.

${ }^{6}$ Майн, В.В. (2013). Етимологічні основи сутності ринку. Науковий вісник Полтавського університету економіки і торгівлі, 1, 73-77.

${ }^{7}$ Афанасьєва, О. П. (2015). Особливості та місце товарного ринку в системі ринків. Глобальні та національні проблеми економіки. Миколаӥвський національний університет імені В.О. Сухомлинського, 3, 3-8. <http://global-national.in.ua/archive/3-2015/02.pdf> (2021, січень, 25).

8 Логоша, Р. В. (2017). Розвиток ринку овочевої продукції в Україні: теорія, методологія, практика: дисертація на здобуття наукового ступеня доктора економічних наук. Житомир: Житомирський національний агроекологічний університет $<$ http://znau.edu.ua/images//images-news/2018/04/Дисертація_Логоша_P.B.PDF> (2021, січень, 28).
} 
суспільство (3 XIX ст.); постіндустріальне суспільство (XXI ст.)- ринкова економіка постіндустріального типу (ринок постіндустріального типу). 3 метою формулювання авторського визначення категорії «ринок» проаналізуємо основні трактування цієї категорії провідними вченими, наголошуючи на тому, що досліджень щодо сутності ринку на сьогодні економічна теорія, маркетинг та менеджмент змогли накопичити дуже багато, отже ми розглядаємо лише деякі з них (табл. 1).

Таблиця 1

Трактування категорії «ринок» у наукових працях ${ }^{1}$

\begin{tabular}{|c|c|}
\hline Автор (и) & Визначення \\
\hline $\begin{array}{l}\text { Волянська-Савчук Л., } \\
\text { Красовський В. }\end{array}$ & $\begin{array}{l}\text { сукупність соціально-економічних відносин у сфері обміну, за допомогою яких } \\
\text { здійснюється купівля-продаж товарів й остаточне визнання їхньої суспільної } \\
\text { цінності }\end{array}$ \\
\hline Загороднюк О. & $\begin{array}{l}\text { середовище, в якому люди вступають у взаємовідносини з приводу купівлі- } \\
\text { продажу товарів і послуг, а також капіталу за взаємоузгодженою ціною на основі } \\
\text { попиту і пропозиції }\end{array}$ \\
\hline Задоя А., Петруня Ю. & $\begin{array}{l}\text { спосіб взаємодії економічних суб’єктів, в основі якого лежить цінова система та } \\
\text { конкуренція }\end{array}$ \\
\hline Далан Е., Ліндсей Д. & будь-яка взаємодія, в яку вступають люди для обміну одне з одним \\
\hline Котлер Ф. & сукупність наявних та потенційних покупців товару \\
\hline Курно А. & $\begin{array}{l}\text { будь-який район, де взасмовідносини покупців і продавців настільки вільні, що } \\
\text { ціни на одні й ті ж самі товари мають тенденцію легко і швидко вирівнюватися }\end{array}$ \\
\hline $\begin{array}{l}\text { Макконнелл К., } \\
\text { Брю С. }\end{array}$ & $\begin{array}{l}\text { інститут або механізм, який зводить разом покупців (представників попиту) і } \\
\text { продавців (постачальників) окремих товарів і послуг }\end{array}$ \\
\hline Марціняк C. & $\begin{array}{l}\text { сукупність економічних умов, в яких укладаються обмінні трансакції між } \\
\text { продавцями, що пропонують товари та послуги, і покупцями, які мають потреби } \\
\text { в них, що підкріплюється відповідними фінансовими розрахунками }\end{array}$ \\
\hline Маршалл А. & $\begin{array}{l}\text { район, де відносини покупців і продавців настільки вільні, що ціни на одні і ті ж } \\
\text { товари легко вирівнюються }\end{array}$ \\
\hline Мочерний C. & $\begin{array}{l}\text { певна сукупність економічних відносин між індивідами з приводу купівлі-продажу } \\
\text { товарів і послуг відповідно до законів товарного виробництва }\end{array}$ \\
\hline Насіловський М. & $\begin{array}{l}\text { форма зв’язків між виробниками; виробниками і домогосподарствами; } \\
\text { виробниками і домогосподарствами та різними фінансовими інституціями; } \\
\text { фінансовими інституціями і центральним банком; усіма названими суб'єктами та } \\
\text { центральною і локальною владою }\end{array}$ \\
\hline Осипов Ю. & $\begin{array}{l}\text { суспільство підприємців, що є цілісною самоорганізованою системою, яка виконує } \\
\text { функцію соціального організатора суспільного виробництва і здійснює } \\
\text { мікрогосподарювання }\end{array}$ \\
\hline Пезенті А. & $\begin{array}{l}\text { умовне місце, куди сходяться виробники товарів, які пропонують свій товар } \\
\text { покупцям, і покупці, які пред’являють попит на товар }\end{array}$ \\
\hline
\end{tabular}

\footnotetext{
${ }^{1}$ Волянська-Савчук, Л. В., Красовський, В. О. (2019). Теоретичні засади ринку праці в економічній системі. Економіка і організація управління, 1 (33), 21-32; Загороднюк, О. В. (2009). Теоретична сутність ринку, його функції та структурні складові. Формування ринкової економіки: збірник наукових праць ДВНЗ «Київський начіональний економічний університет ім. Вадима Гетьмана», 279-288; Камінська, А. І. (2015). Теоретичні засади формування категорії «ринок» в процесі еволюції економічної думки. Економіка та управління АПК, 2, 38-43; Майн, В. В. (2013). Етимологічні основи сутності ринку. Науковий вісник Полтавського університету економіки і торгівлі, 1, 73-77; Котлер, Ф. (1990). Основы маркетинга. Москва, 736; Чухно, А. А. (2006). Становлення і розвиток ринкової економіки. Київ, 1,560 ; Рудакова, И. Е. и др. (1992). Современный рынок: природа и развитие. Москва: МГУ, 133; Milewski, R., Kwiatkowski, Е. (red.) (1998). Podstawy ekonomii. Warszawa: PWN, 682; Marciniak, S. (2002). Makro i mikroekonomia: podstavove problemy. Warszawa, 595; Nasiłowski, M. (1998). System rynkowy: Podstawymikro- i makroekonomii. Warszawa: Key Text, 464; Супіханов, Б. К. (2009). Розвиток ринків аграрної продукції. Київ: ННЦ «Ін-т аграрної економіки», 538; Рабинович, И. А. (1993). Маркетинг в коммерческой деятельности. Одесса: Интмар, 248; Саблук, П. Т., Карич, Д. Я., Коваленко, Ю. С. (2002). Основи організаиї̈ сільськогосподарського ринку. Київ: IAЕ УААН, 190.
} 
Продовження табл. 1

\begin{tabular}{|l|l|}
\hline \multicolumn{1}{|c|}{ Автор (и) } & \multicolumn{1}{c|}{ Визначення } \\
\hline Рабинович І. & $\begin{array}{l}\text { сукупність соціально-економічних процесів, що відбуваються у сфері обміну, завдяки } \\
\text { яким реалізується вартість товарів і узгоджуються інтереси їх виробників і споживачів }\end{array}$ \\
\hline $\begin{array}{l}\text { Саблук П., Карич Д., } \\
\text { Коваленко Ю. }\end{array}$ & $\begin{array}{l}\text { цілеспрямовано упорядкована система ресурсів, установ і методів, завданням якої є } \\
\text { створення і підтримання ринкового середовища в стані, максимального } \\
\text { наближення до чистої конкуренції і здатності генерувати ринкові ціни, як ціни } \\
\text { попиту та пропозиції }\end{array}$ \\
\hline Хейне П. & набір взаємозв'язків або процес конкурентних торгів \\
\hline Яблонський А. & сукупність трансакцій купівлі та продажу й умов, в яких вони здійснюються \\
\hline
\end{tabular}

Джерело: систематизовано авторами

Таким чином, ринок є багатогранним та ємним явищем, а більшість економістів розглядають ринок як: обмін, організований за законами товарного виробництва та обігу; механізм створення додаткової вартості; економічний простір, де відбувається обмін товарів; сукупність економічних взаємовідносин між продавцями і покупцями в процесі купівлі-продажу товарів та послуг; один з головних елементів системи господарювання. Слід відмітити, що незважаючи на істотний час дослідження даної категорії чотири сутнісні характеристики ринку залишились незмінними: попит, пропозиція, ціна і конкуренція ${ }^{1}$. Отже, з огляду на полісемічність цієї категорії, слід відмітити, поперше: ця категорія може розглядатися як у широкому, так і у вузькому розумінні; по-друге, ринок доцільно всебічно й комплексно розглядати з позицій визначення економічного змісту, організаційного механізму, внутрішньої структури й управлінського аспекту. Виходячи з цього, вважаємо, що ринок являє собою організовану і збалансовану систему: елементів «попит», «пропозиція», «конкуренція» та «ціна», які знаходяться у постійній взаємодії; соціально-економічних взаємозв'язків, що мають місце у сфері обміну товарів, робіт, послуг та інформації між суб’єктами господарювання.

Розгляд ринку як системи дозволяе висунути гіпотезу, що ринок так само, як інші соціальноекономічні системи, має свій життєвий цикл, тобто сукупність взаємопов'язаних процесів послідовної зміни стану ринку як системи. Оскільки в історичному аспекті ми можемо виокремити стадію зародження ринку, але не можемо виділити заключну, вважатимемо, що кінцевою стадією є перехід ринку як системи на якісно новий рівень. Таким чином, життєвий цикл ринку, з нашої точки зору, має спіралеподібну структуру з наступними основними фазами: досистемний стан - повільне зростання пришвидшене зростання - зростаюча стабілізація - скорочена стабілізація - повільне скорочення швидке скорочення - післясистемний стан.

Розвиток світової економіки в значній мірі пов'язаний із еволюційною трансформацію категорії ринок. За останні 1,5 тисячі років відбулись значні трансформації (переважно в останні 150 років), усфері структури та функцій ринку. Заслуговує на увагу модель еволюції видів ринків, запропонована колективом авторів ${ }^{2}$, згідно 3 якою ринок виник й отримав розвиток саме як ринок матеріальних товарів; 3 появою більш складних матеріальних товарів 3'явився ринок обслуговування; у подальшому сформувався ринок товарів та послуг, на який почали поставляти товар у вигляді виробу плюс послуга; з розширенням асортименту послуг й ускладненням процесу формування послуг організовано виробництво різноманітних інформаційних продуктів, попит на які призвів до появи посередників; поява Інтернету сприяла діленню ринків на традиційні з використанням тих самих форм i появі електронних ринків; у процесі еволюції інформаційних і комунікаційних технологій виникла необхідність конвергенції послуг в інфокомунікаційні; наразі формується інтегральний глобальний ринок інформаційної економіки.

Еволюційна трансформація видів ринку значною мірою вплинула на створення істотної кількості нових типів ринків відповідно до економічних, інфраструктурних та фінансових відмінностей. Проаналізуємо ключові класифікації типів ринків, що існують на сьогоднішній день в системі світової економіки, задля чого скористаємося нижченаведеної таблицею (табл. 2), в якій наочно відображені дані типи ринків та їх класифікаційні ознаки.

\footnotetext{
${ }^{1}$ Майн, В. В. (2013). Етимологічні основи сутності ринку. Науковий вісник Полтавського університету економіки і торгівлі, 1, 73-77.

${ }^{2}$ Стрій, Л. А., Захарченко, Л. А., Голубєв, А. К. (2014). Модель еволюції видів ринків. Науковий вісник

Херсонського державного університету, 7 (4), 99-103.
} 
Класифікація типів ринку ${ }^{1}$

\begin{tabular}{|c|c|}
\hline Класифікаційна ознака & Типи ринку \\
\hline $\begin{array}{l}\text { За структурою господарства } \\
\text { країни } \\
\end{array}$ & $\begin{array}{c}\text { країн з економікою типу натурального господарства, країн-експортерів } \\
\text { сировини, промислово розвинених країн }\end{array}$ \\
\hline За географічним положенням & $\begin{array}{c}\text { місцевий, регіональний, внутрішній (національний), зовнішній } \\
\text { (світовий) }\end{array}$ \\
\hline $\begin{array}{c}\text { За товарно-галузевою } \\
\text { багаторівневою деталізацією }\end{array}$ & $\begin{array}{l}\text { машин і устаткування; мінеральної сировини і палива, } \\
\text { сільськогосподарської сировини і продовольчих товарів }\end{array}$ \\
\hline $\begin{array}{l}\text { За економічним призначенням } \\
\text { об’єктів ринкових відносин }\end{array}$ & $\begin{array}{c}\text { товарів матеріального виробництва, інтелектуального продукту, праці, } \\
\text { інвестицій, фінансовий (грошовий), цінних паперів }\end{array}$ \\
\hline $\begin{array}{l}\text { За характером кінцевого } \\
\text { користування товаром }\end{array}$ & товарів виробничого призначення, товарів споживчого користування \\
\hline $\begin{array}{c}\text { За терміном користування } \\
\text { товаром }\end{array}$ & $\begin{array}{c}\text { товарів довгострокового користування, товарів короткострокового } \\
\text { користування, товарів одноразового користування }\end{array}$ \\
\hline За видом часового інституту & реальний, умовний \\
\hline $\begin{array}{c}\text { За ступенем обмеження } \\
\text { конкуренції }\end{array}$ & $\begin{array}{c}\text { досконалої конкуренції, недосконалої конкуренції (монополістичний, } \\
\text { олігополістичний, змішаний) }\end{array}$ \\
\hline За дотриманням законності & $\begin{array}{l}\text { офіційний «легальний», нелегальний «тіньовий», контрабандний, } \\
\text { чорний }\end{array}$ \\
\hline За рівнем насиченості & рівноважний, дефіцитний, надлишковий \\
\hline За ступенем зрілості & нерозвинений, розвинений, ринок, що формується \\
\hline $\begin{array}{c}\text { За якісними характеристиками } \\
\text { товарів }\end{array}$ & високотехнологічний, низькотехнологічний \\
\hline За асортиментом товарів & замкнений, насичений, різноманітного асортименту, змішаний \\
\hline За обсягами продажу & оптовий, споживчий (роздрібний) \\
\hline За рівнем регулювання & регульований, нерегульований \\
\hline За способом формування & стихійний, організований \\
\hline За характером входу та виходу & відкритий, закритий, преференційний \\
\hline За ступенем насиченості ринку & концентрований, неконцентрований \\
\hline $\begin{array}{l}\text { За характером торгівельних } \\
\text { зв'язків }\end{array}$ & інтенсивний, неінтенсивний \\
\hline $\begin{array}{c}\text { За характером попиту та } \\
\text { пропозиції }\end{array}$ & симетричний, асиметричний \\
\hline За умовами функціонування & насичений, ненасичений \\
\hline За рівнем стабільності & стабільний, нестабільний \\
\hline За суб’єктним складом & продавця, покупця, посередника \\
\hline За типом взаємозв'язків & вертикальні, горизонтальні \\
\hline За ступенем державного впливу & адміністративний, вільний, квазіринок \\
\hline
\end{tabular}

Джерело: систематизовано авторами.

\footnotetext{
${ }^{1}$ Майн, В. В. (2013). Етимологічні основи сутності ринку. Науковий вісник Полтавського університету економіки і торгівлі, 1, 73-77; Попадинець, Н. М. (2015). Внутрішній ринок: підходи до визначення. Соціально-економічні проблеми сучасного періоду Украӥни, 6, 124-129; Мішеніна, Г. А., Матвєєва, Ю. Т. (2015). Дослідження ринку. Суми: Сумський державний університет, 185; Бодров, В. Г., Балдич, Н. І., Гусєв, В. О. (2011). Внутрішній ринок України: теорія та стратегія посткризового розвитку. Київ: НАДУ, 80; Макаренко, П. М., Сень, О. В. (2012). Теоретичні аспекти сутності ринку та його видів. Наукові праці Полтавської державної аграрної академії (ПДАА), 1 (4), 2, 3-21.
} 
В той самий час окремі вчені пропонують здійснювати класифікацію типів ринків на основі ключових функцій ${ }^{1} .3$ урахуванням еволюційних перетворень в системі фундаментальних основ функціонування ринку здійснюється й розвиток наукової думки у сфері кількості та диференціації функцій ринку. У контексті предметного розкриття тематики даного наукового дослідження здійснимо порівняльний аналіз функцій ринку, що виділяють у своїх працях вітчизняні науковці, задля чого скористаємося нижченаведеною таблицею (табл. 3).

Таблиця 3

Функції ринку ${ }^{2}$

\begin{tabular}{|c|c|c|c|c|c|c|c|c|c|c|}
\hline Функції & 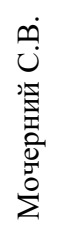 &  & 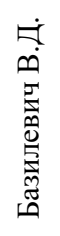 & 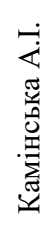 & $\begin{array}{l}\dot{0} \\
0 \\
0 \\
0 \\
0 \\
0 \\
0\end{array}$ & 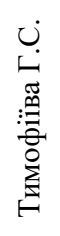 & 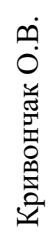 & 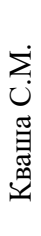 & 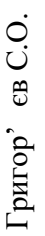 & 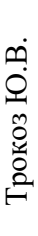 \\
\hline Ціноутворююча & + & + & + & + & + & + & + & + & + & + \\
\hline Відтворювальна & + & + & + & & & + & + & & & + \\
\hline Стимулююча & + & + & + & + & + & + & + & + & + & + \\
\hline Регулююча & + & + & + & + & + & + & + & + & + & + \\
\hline Контролююча & + & + & + & + & & & & & & + \\
\hline Сануюча & + & + & + & + & & + & + & + & + & + \\
\hline Інтегруюча & & + & + & + & & + & + & + & + & \\
\hline Розподільча (розподільна) & & & + & & & + & + & + & + & \\
\hline Інформаційна & & & + & + & + & + & + & + & + & + \\
\hline Функція розвитку & & & & + & & + & + & & & \\
\hline Посередницька & & & & & + & + & + & + & + & \\
\hline Стабілізуюча & & & & & & + & + & + & + & \\
\hline Функція посилення конкуренції & & & & & & + & + & + & + & + \\
\hline Техніко-економічна & & & & & & & & + & + & \\
\hline Алокаційна & & + & & & & + & + & & & \\
\hline
\end{tabular}

Джерело: систематизовано авторами

Незважаючи на значне розгалуження класифікацій та видів функцій ринку, переважна більшість науковців сходиться у думці, що найбільш фундаментальними функціями ринку є: ціноутворююча, стимулююча, регулююча, сануюча, та інформаційна. Розвиток ринкових відносин, та еволюційна трансформація структури ринку дозволяють виділити на сьогоднішній день шість ключових ринкових структур (табл. 4).

\footnotetext{
${ }^{1}$ Майн, В. В. (2013). Етимологічні основи сутності ринку. Науковий вісник Полтавського університету економіки і торгівлі, 1, 73-77.

2 Логоша, Р. В. (2020). Концептуальне відображення еволюції ринку та цивілізації як єдиного процесу. Wschodnioeuropejskie Czasopismo Naukowe: East European Scientific Journal, 3, 23-33; Кваша, С. М., Григор'єв, С. О. (2016). Сутність та особливості аграрного ринку. Вісник ОНУ ім. I.I. Мечникова, 5, 56-59; Загороднюк, О.В. (2009). Теоретична сутність ринку, його функції та структурні складові. Формування ринкової економіки: збірник наукових пращь ДВНЗ «Київський наџіональний економічний університет ім. Вадима Гетьмана», 1, 279-288; Камінська, А. І. (2015). Теоретичні засади формування категорії «ринок» в процесі еволюції економічної думки. Економіка та управління АПК, 2, 38-43; Щеглов, О. Ю. (2011). Функції ринку в сучасних економічних умовах. Формування ринкових відносин в Україні, 4, 148-153; Трокоз, Ю. (2017). Економічна суть, зміст ринку агропродовольчої продукції та практичні рекомендації щодо стимулювання зростання АПК. Економіка та держава, 8, 99-104 < http://www.economy.in.ua/pdf/8_2017/25.pdf> (2021, січень, 30).
} 
Ключові ринкові структури та їх загальні характеристики ${ }^{12}$

\begin{tabular}{|c|c|c|c|c|}
\hline Структура ринку & $\begin{array}{c}\text { Обмеження входу для } \\
\text { продавців }\end{array}$ & Кількість продавців & $\begin{array}{c}\text { Обмеження входу для } \\
\text { покупців }\end{array}$ & $\begin{array}{c}\text { Кількість } \\
\text { покупців }\end{array}$ \\
\hline $\begin{array}{c}\text { Досконала } \\
\text { конкуренція }\end{array}$ & Не має & Багато & Не має & Багато \\
\hline $\begin{array}{c}\text { Монополістична } \\
\text { конкуренція }\end{array}$ & Не має & Багато & Не має & Багато \\
\hline Олігополія & $€$ & Небагато & Не має & Багато \\
\hline Олігопсонія & Немає & Багато & $\epsilon$ & Небагато \\
\hline Монополія & $€$ & Один & Не має & Багато \\
\hline Монопсонія & Немає & Багато & $\epsilon$ & Один \\
\hline
\end{tabular}

Більшість сучасних вчених виокремлюють «досконалу конкуренцію» як найбільш прийнятну модель розвитку ринку майбутнього. У той самий час необхідно розуміти, що реалізація даної концепції можлива лише за процесу тотальної глобалізації ринків суверенних держав з одного боку та розбудови й дотримання єдиних правил та механізмів функціонування глобального ринку в структурі світової економіки.

3 80-х років XX століття процес глобалізації розповсюджується на сферу інноваційних технологій - людство вступає в новий етап розвитку, техноглобалізм. Відповідно до цього, слід виокремити наступні тенденції розвитку ринку в умовах техноглобалізму: стрімкий розвиток інформаційно-телекомунікаційних технологій, провідна роль знань та інтелектуального капіталу, підвищення рівня відкритості національних економік, інтенсифікація обміну передовими досягненнями людства, посилення нерівномірності економічного розвитку та технологічного розриву між країнами, зростаюча політична взаємозалежність країн світу, загострення екологічних проблем, витіснення людського капіталу машинами тощо.

Висновки та перспективи подальших досліджень. Проведене дослідження дозволяє зробити наступні висновки. По-перше, актуальність вивчення історичної трансформації економічної думки відносно категорії «ринок» пов'язана з необхідністю побудови в Україні сучасного та ефективного ринку задля забезпечення відповідного рівня конкурентоспроможності економіки в умовах техноглобалізму. По-друге, економічна категорія «ринок» зазнала значних трансформаційних змін відповідно до сутнісних характеристик, видів, типів та ключових функцій, що в значній мірі було викликано еволюцією грошово-кредитної системи та розвитком науково-технічного прогресу. Потретє, зважаючи на те, що провідні країни світу розвиваються на сьогоднішній день в системі побудови єдиного цифрового ринку на умовах абсолютної конкуренції, це дає змогу зрозуміти, що вітчизняні механізми стимулювання ринкового розвитку та управління ринком повинні бути спрямованні на досягнення гармонізації інтересів суб'єктів вітчизняного ринку та суб'єктів ринків країн із розвиненою економікою. У перспективі подальших досліджень - формування науковометодологічного підгрунтя розробки концепції життєвого циклу ринку і концепції розвитку ринку в умовах техноглобалізму.

\section{References:}

1. Oleksenko, R. I. (2018). Filosofiia rynkovykh vidnosyn u istoryko-ekonomichnomu dyskursi suchasnykh ukrainskykh vchenykh [Philosophy of market relations in the historical and economic discourse of modern Ukrainian scientists]. Hileia [Gileya], 137, 79-90. [in Ukrainian].

2. Simkiv, L. Ye. (2020). Rynkova infrastruktura: elementy ta znachennia v rynkovii ekonomitsi [Market infrastructure: elements and meanings in a market economy]. Socio-economic problems of the modern period of Ukraine, 4, 3-7. [in Ukrainian].

3. Zahorodniuk, O. V. (2009). Teoretychna sutnist rynku, yoho funktsii ta strukturni skladovi [Theoretical essence of the market, its functions and structural components]. Formuvannya rynkovoyi ekonomiky: zbirnyk naukovykh

\footnotetext{
${ }^{1}$ Майн, В. В. (2013). Етимологічні основи сутності ринку. Науковий вісник Полтавського університету економіки і торгівлі, 1, 73-77.

2 Тарасенко, Л. О. (2017). Теоретичні аспекти конкуренції та монополії: сутність, особливості, наслідки. Фінанси, облік, банки, 1, 260-268.
} 
prats DVNZ «Kyivskyy natsionalnyy ekonomichnyy universytet im. Vadyma Hetmana» [The formation of a market economy: a collection of scientific papers SHEI "Kyiv National Economic University. Vadim Hetman"], $279-288$. [in Ukrainian].

4. Oxford dictionary (1970). Market. Oxford: Clarendon Press, V-VI, 172-173. [in English].

5. Makarenko, P. M., Sen, O. V. (2012). Teoretychni aspekty sutnosti rynku ta yoho vydiv [Theoretical aspects of the essence of the market and its types]. Naukovi pratsi Poltavskoi derzhavnoi ahrarnoi akademii [Scientific works of Poltava State Agrarian Academy], 1 (4), 2, 3-21. [in Ukrainian].

6. Main, V. V. (2013). Etymolohichni osnovy sutnosti rynku [Etymological bases of the essence of the market]. Naukovyi visnyk Poltavskoho universytetu ekonomiky i torhivli [Scientific Bulletin of Poltava University of Economics and Trade], 1, 73-77. [in Ukrainian].

7. Afanasieva, O. P. (2015). Osoblyvosti ta mistse tovarnoho rynku v systemi rynkiv [Features and place of the commodity market in the system of markets]. Hlobalni ta natsionalni problemy ekonomiky. Mykolaivskyi natsionalnyi universytet imeni V.O. Sukhomlynskoho [Global and national economic problems. Nikolaev National University named after VO Sukhomlinskoho], 3, 3-8. <http://global-national.in.ua/archive/3-2015/02.pdf> (2021, January 25). [in Ukrainian].

8. Lohosha, R. V. (2017). Rozvytok rynku ovochevoi produktsii v Ukraini: teoriia, metodolohiia, praktyka [Development of the market of vegetable products in Ukraine: theory, methodology, practice]: dysertatsiya na zdobuttya naukovoho stupenya doktora ekonomichnykh nauk [dissertation for the degree of Doctor of Economics]. Zhytomyr: Zhytomyr National Agroecological University <http://znau.edu.ua/images//imagesnews/2018/04/Дисертація_Логоша_P.B.PDF> (2021, January 28). [in Ukrainian].

9. Volianska-Savchuk, L. V., Krasovskyi, V. O. (2019) Teoretychni zasady rynku pratsi v ekonomichnii systemi [Theoretical principles of the labor market in the economic system]. Ekonomika i orhanizatsiia upravlinnia [Economics and organization of management], 1 (33), 21-32. [in Ukrainian].

10. Kaminska, A. I. (2015). Teoretychni zasady formuvannia katehorii «rynok» v protsesi evoliutsii ekonomichnoi dumky [Theoretical principles of formation of the category "market" in the process of evolution of economic thought]. Ekonomika ta upravlinnia APK [Economics and management of agro-industrial complex], 2, 38-43. [in Ukrainian].

11. Kotler, F. (1990). Osnovy marketinga. [Basics of marketing]. Moscow. [in Russian].

12. Chukhno, A. A. (2006) Stanovlennia i rozvytok rynkovoi ekonomiky [Formation and development of a market economy], Kyiv, 1, 560. [in Ukrainian].

13. Rudakova, I.E. and others (1992). Sovremennyj rynok: priroda i razvitie [Modern market: nature and development]. Moscow. [in Russian].

14. Podstawy ekonomii (1998). [Basics of economics].Warszawa : PWN, 682. [in Polish].

15. Marciniak, S. (2002). Makro i mikroekonomia: podstavove problemy [Macro and microeconomics: basic problems]. Warszawa. [in Polish].

16. Nasiłowski, M. (1998). System rynkowy: Podstawymikro- i makroekonomii [Market system: The basis of micro and macroeconomics]. Warszawa: Key Text. [in Polish].

17. Supikhanov, B. K. (2009). Rozvytok rynkiv ahrarnoi produktsii [Development of agricultural markets]. Kyiv, NNTs Instytutt ahrarnoi ekonomiky. [in Ukrainian].

18. Rabinovich, I. A. (1993). Marketing v kommercheskoj dejatel'nosti [Commercial Marketing]. Odessa, Intmar. [in Russian].

19. Sabluk, P. T., Karych, D. Ya., Kovalenko, Yu. S. (2002). Osnovy orhanizatsii silskohospodarskoho rynku [Fundamentals of agricultural market organization]. Kyiv, IAE UAAN. [in Ukrainian].

20. Strii, L. A., Zakharchenko, L. A., Holubiev, A. K. (2014). Model evoliutsii vydiv rynkiv [Model of evolution of market types]. Naukovyi visnyk Khersonskoho derzhavnoho universytetu [Scientific Bulletin of Kherson State University]. 7(4), 99-103. [in Ukrainian].

21. Lohosha, R. V. (2020). Kontseptualne vidobrazhennia evoliutsii rynku ta tsyvilizatsii yak yedynoho protsesu [Conceptual reflection of the evolution of the market and civilization as a single process]. Wschodnioeuropejskie Czasopismo Naukowe: East European Scientific Journal [East European Scientific Journal: East European Scientific Journal], 3, 23-33. [in Ukrainian].

22. Popadynets, N. M. (2015). Vnutrishnii rynok: pidkhody do vyznachennia [Internal market: approaches to definition]. Sotsialno-ekonomichni problemy suchasnoho periodu Ukrainy [Socio-economic problems of the modern period of Ukraine], 6, 124-129. [in Ukrainian].

23. Mishenina, H. A., Matvieieva, Yu. T. (2015). Doslidzhennia rynku [Market research]. Sumy, Sumskyi derzhavnyi universytet. [in Ukrainian].

24. Bodrov, V. H., Baldych, N. I., Husiev, V. O. (2011). Vnutrishnii rynok Ukrainy: teoriia ta stratehiia postkryzovoho rozvytku [Internal market of Ukraine: theory and strategy of post-crisis development]. Kyiv, NADU. [in Ukrainian].

25. Kvasha, S. M., Hryhoriev, S. O. (2016). Sutnist ta osoblyvosti ahrarnoho rynku [The essence and features of the agricultural market]. Visnyk ONU im. I.I. Mechnykova [Bulletin of Mechnikov' Odessa National University], 5, 56-59. [in Ukrainian]. 
26. Shchehlov, O. Yu. (2011). Funktsii rynku v suchasnykh ekonomichnykh umovakh [Market functions in modern economic conditions]. Formuvannia rynkovykh vidnosyn v Ukraini [Formation of market relations in Ukraine], 4, 148-153. [in Ukrainian].

27. Trokoz, Yu. (2017). Ekonomichna sut, zmist rynku ahroprodovolchoi produktsii ta praktychni rekomendatsii shchodo stymuliuvannia zrostannia APK [Economic essence, content of the agri-food market and practical recommendations for stimulating the growth of agro-industrial complex]. Ekonomika ta derzhava [Economy and state], 8, 99-104. <http://www.economy.in.ua/pdf/8_2017/25.pdf> (2021, January 30). [in Ukrainian].

28. Tarasenko, L. O. (2017). Teoretychni aspekty konkurentsii ta monopolii: sutnist, osoblyvosti, naslidky [Theoretical aspects of competition and monopoly: essence, features, consequences]. Finansy, oblik, banky [Finance, accounting, banks], 1, 260-268. [in Ukrainian]. 